\title{
25 Research Square \\ Environmental Regulations, Competition and Divestment of Foreign Direct Investment: Evidence from China
}

Lufeng Tai

Shanghai University

Linnan Yan ( $\nabla$ yanlinnan123@163.com )

Shanghai University https://orcid.org/0000-0001-8219-343X

\section{Research Article}

Keywords: Divestment of FDI, firm exit, environmental regulations, pollution haven hypothesis, Porter hypothesis

Posted Date: May 24th, 2021

DOl: https://doi.org/10.21203/rs.3.rs-453504/v1

License: (c) (i) This work is licensed under a Creative Commons Attribution 4.0 International License.

Read Full License 


\title{
Environmental Regulations, Competition and Divestment of
}

\section{Foreign Direct Investment: Evidence from China}

Lufeng Tai ${ }^{\mathrm{a}}$, Linnan Yan ${ }^{\mathrm{a}, *}$

a. School of Economics, Shanghai University, 200444 Shanghai, China.

tailufeng123@163.com (L.T.), yanlinnan123@163.com (L.Y.)

*Correspondence: yanlinnan123@163.com; Tel.: +86 18800379686

(1)

\begin{abstract}
This paper is concerned with whether the Chinese increasingly stringent environmental regulations (ER) lead to the divestment of foreign direct investment (FDI). Based on industrial firm-level panel data from 2003 to 2010, our results show that the stricter ER do not induce the divestment of FDI but rather reduce the probability of foreign firms' withdrawal from China. Moreover, in cities with a higher degree of marketization, the ER have greatly reduced the exit probability of foreign firms. The mechanism analysis shows that due to the scale and technological advantages of foreign companies, the ER have stimulated innovation, increased the market share and profits of foreign companies. However, the ER have a greater negative impact on domestic firms' performance. This research has theoretical and empirical significance for the economic development and environmental protection of developing countries.
\end{abstract}

Keywords: Divestment of FDI; firm exit; environmental regulations; pollution haven hypothesis; Porter hypothesis

JEL classification: F21; O13

\section{Introduction}

The pollution haven hypothesis $(\mathrm{PHH})$ suggests that environmental protection policies inevitably increase enterprises' costs, and countries with lower environmental costs are more attractive to multinational enterprises (Copeland and Taylor, 2004). However, the researches on whether the looser ER attracted more FDI have not reached a consistent 
conclusion (Cai et al., 2016; Millimet and Roy, 2016; Muhammad and Khan, 2019; Kim and Rhee, 2019; Santos and Forte, 2020; Dong et al., 2021). Kellenberg (2009) states that "the empirical validity of pollution haven effects continues to be one of the most contentious issues in the debate regarding international trade, foreign investment, and the environment".

As the largest developing country in the world, China provides an excellent example for testing the PHH. Since the 21st century, the Chinese government has continuously enhanced environmental protection policies. Besides, the largest number of FDI industrial firms in China was 77,847 in 2008 , and the latest data was 43,588 in 2019 . This number has decreased by $44 \%$ compared to 2008 . Some scholars worry about that the environmental control policies result in the divestment of FDI in China (Greaney et al., 2017). However, most of the existing studies testing the PHH are conducted from the perspective of foreign capital inflows; whether the stricter ER lead to foreign firms' exit behavior is unknown.

Therefore, our work uses Chinese industrial firm-level data to detect whether the ER induce foreign firms' withdrawal in China. The contributions to the existing literature in this paper are as follows.

- First, most of the existing literature have studied the impact of the ER on the influx of FDI from the macro-level (Cai et al., 2016), and yet we use firm-level data to investigate the PHH from the aspect of the divestment of FDI. A firm's exit behavior is regarded as a decision that relies on balancing benefits and costs in this paper. Our results show that the ER significantly reduce the probability of foreign firms' exit behavior, which provides a new enlightenment for understanding the relationship between ER and FDI.

- Second, we shed light on the moderating effect of market competition. We find that the market competition strengthens the role of the ER in reducing the probability of foreign capital withdrawal. In a particular region with a higher degree of marketization, foreign firms can gain a better performance. The market competition mechanism reveals the decision-making process of enterprises.

The rest of the paper is organized as follows: Section 2 provides a literature review 
of the studies on PHH and develops hypotheses according to the theory and fact. Section 3 establishes the estimation methodology and provides an explanation of variables. Section 4 is the empirical test results of the hypotheses. Section 5 is the discussion of the results, and section 6 is the conclusion.

\section{Literature review and hypothesis}

\subsection{Literature review}

The topic of PHH is the relationship between ER and FDI. The early theoretical literature predicts that international capital will move to countries with lower ER (Chichilnisky, 1994; Motta and Thisse, 1994). But the early empirical studies fail to find conclusive evidence of PHH. Some researchers' conclusions support PHH (Becker and Henderson, 2000; Henderson, 1996; Keller and Levinson, 2002; Chung, 2014). However, there are also some studies that do not support PHH (Eskeland and Harrison, 2003; Javorcik and Wei, 2003; Levinson, 1996). There might be two reasons for the inconsistent empirical conclusions. On the one hand, the samples selected in various studies are different, and PHH might not apply to all industries or regions (Eskeland and Harrison, 2003). On the other hand, the potential endogeneity makes it difficult to accurately reveal the causal relationship between ER and FDI (Levinson and Taylor, 2008).

To explain why the empirical researches do not support PHH, theoretical researchers study the problem from more aspects, such as regional heterogeneity (Zeng and Zhao, 2009; SannaRandaccio and Sestini, 2012) and firm heterogeneity (Dijkstra et al., 2011; Elliott and Zhou, 2013). Zeng and Zhao (2009) introduce agglomeration economies into a two-state model with high transportation costs and imperfect competition. They show that agglomeration economies' benefits might be greater than the reduction of pollution control costs due to relocation.

More recently, empirical researches began to deal with the unobserved heterogeneity and potential endogeneity. However, there is also no consistent conclusion (Cai et al., 2016; Millimet and Roy, 2016; Dong et al., 2021; Muhammad and Khan, 2019; Kim and Rhee, 2019). Cai et al. (2016) use the implementation of the TCZ (implemented by the Chinese government to control SO2 and acid rain) policy as a quasi-natural experiment. They conclude that pollution control reduces the inflow of FDI significantly. Using Chinese FDI outflow data during 2008- 
2018 and applying DID estimation, Dong et al. (2021) find that host countries with more relaxed ER attract FDI from polluting industries. However, Muhammad and Khan (2019) and Kim and Rhee (2019), both using country-level panel data, suggest that stricter ER promote the development of new industries, increase productivity, and attract FDI.

There are also some studies that have reached complex conclusions (Yang et al., 2019; Yu and Li, 2020). Yang et al. (2019) used the spatial Durbin model to test the influence of Chinese urban ER on the inflow of FDI. Their results implicate that the validity of the PHH has a significant regional difference; the level of ER in the eastern (central and western) region of China is positively (negatively) correlated with the FDI introduction. Using Chinese province-level panel data from 2009 to 2018 to explore the PHH, Yu and Li (2020) find that ER do not inhibit the inflow of FDI but improve the quality of FDI.

There are many theoretical and empirical studies on PHH but remain some limitations. First, most researches are carried out from the nation and industry levels, but the inflow and outflow of FDI is actually a kind of corporate behavior. Existing empirical investigations ignore the decision-making behavior of enterprises. Second, the inflow and outflow of FDI are two sides of the same coin. Most of the researches focus on the relationship between ER and inflow of foreign capital, while few on the withdrawal of foreign firms. Therefore, for the sake of environmental protection and stable development of foreign investment, it is of great significance to study whether ER lead to foreign firms' withdrawal. Our work has improved the two limitations and has enriched the literature on $\mathrm{PHH}$. We use microdata to study the $\mathrm{PHH}$ from the perspective of firm exit behavior, and we also consider endogeneity.

\subsection{Hypothesis development}

Many studies suggest that the poor performance and the low profits of overseas subsidiaries are the most fundamental reasons for divestment (Jagersma and Van Gorp, 2003; Hryckiewicz and Kowalewski, 2011). Therefore, whether the stricter ER lead to the divestment of FDI depends on the degree of ER policies' impact on their business performance.

Porter hypothesis suggests that ER can force firms to engage in innovation, and the compensation effect of innovation may eventually exceed the costs of pollution control (Porter and 
vander Linde, 1995). Firms may reduce their investment due to ER's additional expenses in the short term, but in the long run, technological progress can decrease the costs (Jaffe et al., 2002). Many studies supporting Porter hypothesis show that ER positively impact firm performance (Dasgupta et al., 2006; Ramanathan et al., 2010; Kneller and Manderson, 2012). Lee (2020) uses Chinese listed company data to study, and he find that both command and control ER and voluntary instruments positively affect the firm financial performance.

Besides, the costs increase caused by the stricter ER might vary from company to company. Dijkstra et al. (2011), using a Cournot duopoly three-stage model, show that ER could increase all companies' costs, including domestic companies. But if a foreign firm has more efficient technology than a domestic firm, the ER could give the foreign firm a greater cost advantage. According to Schumpete's theory, large companies have more competitive and innovative advantages than small companies. Figure 1 is the kernel density estimation of domestic and foreign industrial firms' gross output and assets in China. The graphs indicate that the scale of foreign firms is larger than that of domestic firms. Most Chinese foreign firms come from developed countries, and their technological level is relatively higher than the domestic firms. The foreign firms are insensitive to China's ER (Dean et al., 2009). Therefore, the foreign firms are less affected by the stricter ER due to their large scale, advanced technology, and more competitiveness, which have no reasons to leave China. Thus, we develop the following hypothesis:

H1: Stricter ER can reduce the probability of foreign firms leaving China, i.e. ER have a negative effect on firms' exit behavior. 

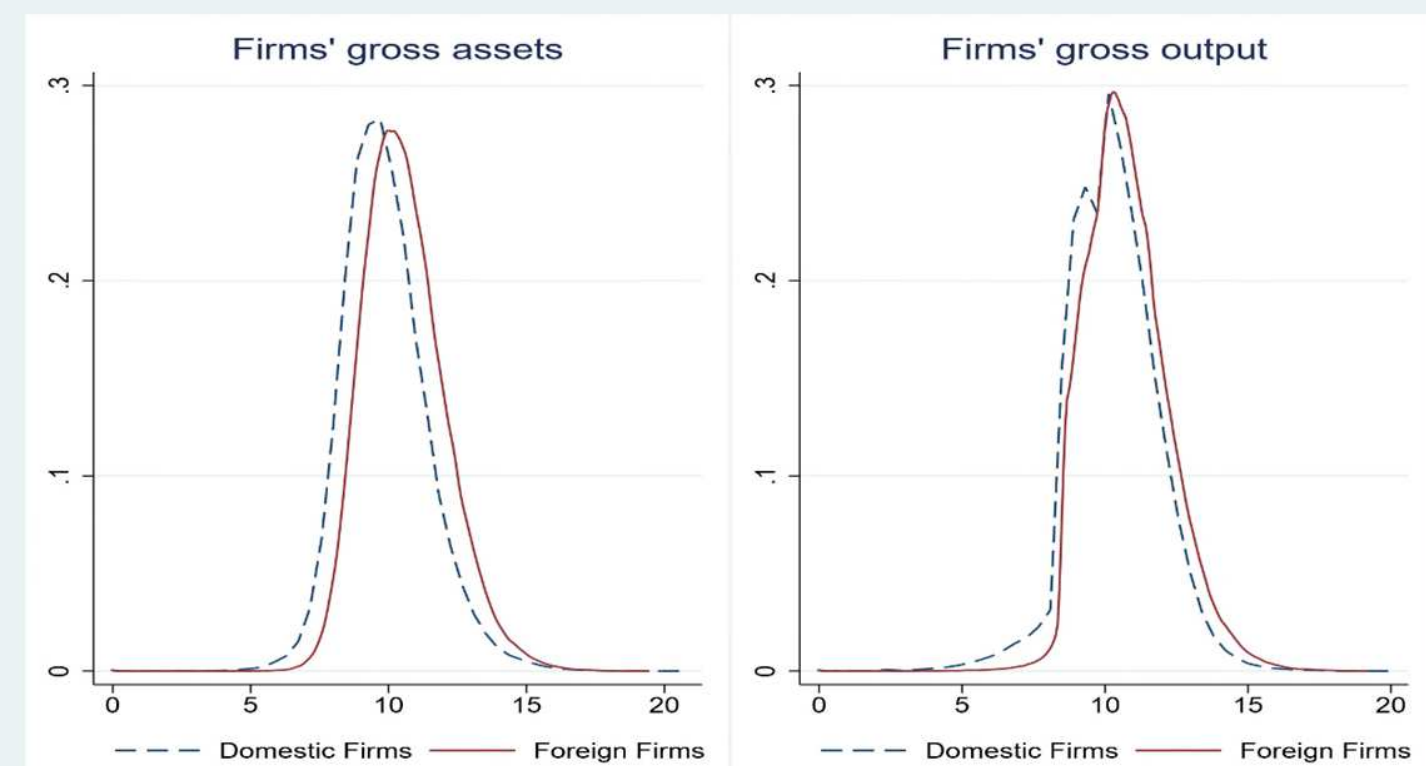

142

143

144

145

146

147

148

149

150

151

152

153

154

155

156

157

Fig 1 The kernel density estimation of the scale of foreign firms and domestic firms.

Another issue sheds light on the role of market competition in regulating the relationship between ER and FDI. Porter hypothesis suggests that firms can gain a competitive advantage through first-mover advantage or differentiation strategy by adopting ER (Porter, 1991). SannaRandaccio and Sestini (2012) take advantage of an international duopoly model to show that stricter regulation does not induce firms to relocate in a country with larger market size. Foreign firms could obtain greater competitive advantages due to their scale and technological advantages. However, China began to implement market-oriented reforms in 1992, and the degree of marketization varies widely in different regions. 'To support the SOEs' (state-owned enterprises) role, government intervention has ensured the allocation of resources to them, and positioned SOEs at the higher tiers of the value chain' (Lee, 2020). If the market is highly controlled and monopolized by SOEs, the foreign firms cannot use their competitive advantages and might be squeezed out of the market.

On the contrary, if a particular region has a higher degree of marketization, even if the ER become stricter, the foreign companies can use their scale and technological advantages to obtain competitive advantages and exhibit better financial performance. Javeed et al. (2020) show that the high degree of competition has a significant and positive moderating effect on the relationship between ER and firm performance. Therefore, we develop the following hypothesis: $\mathrm{H} 2$ : There is a moderating effect of competition on the relationship between ER and foreign 
firms' exit behavior, i.e. in cities that with a higher degree of marketization, ER have a more negative impact on firms' exit behavior.

\section{Methodology and variables}

\subsection{Methodology}

To investigate the impact of ER on the foreign firms' exit, considering the potential problem of missing variables, enterprise heterogeneity and data availability, we develop the benchmark model as follows:

$$
\mathrm{EXIT}_{\mathrm{it}}=\alpha_{0}+\alpha_{1} \mathrm{ER}_{\mathrm{ct}}+\alpha_{2} \mathrm{X}_{\mathrm{it}}+\alpha_{3} \mathrm{Z}_{\mathrm{ct}}+\gamma_{\mathrm{c}}+\lambda_{\mathrm{j}}+\theta_{\mathrm{t}}+\varepsilon_{\mathrm{it}}
$$

Where $i, c, j$ and t represent the firm, city, industry and year, respectively. EXIT $_{i t}$ is the dependent variable denotes the exit behavior of the firm $\mathrm{i}$, and $\mathrm{ER}_{\mathrm{ct}}$ is the independent variable which denotes the ER. $X_{i t}$ and $Z_{c t}$ represent the firm-level and city-level control variables. $\gamma_{c}, \lambda_{j}, \theta_{t}$ represent city, industry and time effects to control unobserved factors and heterogeneity. $\varepsilon_{i t}$ is the random error.

The dependent variable is the exit behavior of the enterprise; it is a dummy variable which equals to 1 if firm i exits in year t, and 0 otherwise. Following Greenaway et al. (2008) and Eslava et al. (2013), we mainly use the probit model to estimate Eq (1). The probit model is non-linear, and the linear model is also unbiased in estimating this problem; therefore, the linear probability model (LPM) is used as a robustness test. From our framework, we expect that ER will reduce the exit probability of foreign companies, that is, we expect $\alpha_{1}<0$.

Second, in order to verify the moderating role of market competition in Hypothesis 2, we introduce the market competition variable (and the interaction term with ER) into Eq (1). The following model is set:

$$
\mathrm{EXIT}_{\mathrm{it}}=\beta_{0}+\beta_{1} \mathrm{ER}_{\mathrm{ct}}+\beta_{2} \mathrm{MC}_{\mathrm{ct}}+\beta_{3} \mathrm{ER}_{\mathrm{ct}} \cdot \mathrm{MC}_{\mathrm{ct}}+\beta_{4} \mathrm{X}_{\mathrm{it}}+\beta_{5} \mathrm{Z}_{\mathrm{ct}}+\gamma_{\mathrm{c}}+\lambda_{\mathrm{j}}+\theta_{\mathrm{t}}+
$$

$\varepsilon_{\mathrm{it}}$

$$
\mathrm{MC}_{\mathrm{ct}} \text { represents market competition which is the moderating variable, } \mathrm{ER}_{\mathrm{ct}} \cdot \mathrm{MC}_{\mathrm{ct}} \text { is the }
$$


interaction term of ER and market competition, and other settings are the same as Eq (1). We estimate Eq (2) using the same method as Eq (1). The hypothesis 2 implicates that in cities with a high degree of market competition, ER greatly reduce the probability of foreign firms exit; i.e. we expect $\beta_{3}<0$.

In addition, to explore the mechanism of ER on firm exit, we further study the impact of ER on corporate performance. Model 3 is set as follows:

$$
P e r_{i t}=\gamma_{0}+\gamma_{1} E R_{e t}+\gamma_{2} X_{i t}+\gamma_{3} Z_{c t}+\zeta_{i}+\theta_{t}+\varepsilon_{i t}
$$

Where $\mathrm{Per}_{i t}$ is the performance variable of firm $\mathrm{i}$ in period $\mathrm{t}$, we use the fixed effects model to estimate $\mathrm{Eq}(3) . \zeta_{i}$ is firm fixed effects which controls those non-time variables of firm level, and other variables are the same as Eq (1). The potential reason why ER will not cause foreign companies to leave China is that ER improve the performance of foreign companies, so we expect $\gamma_{1}>0$.

\subsection{DATA}

In this paper, we draw on both city-level and firm-level data. City-level data are 2003-2010 yearly data from the Chinese City Statistical Yearbook, which includes 290 Chinese cities. This data contains indicators of the city's economic development and environmental governance. The firm-level data are sourced from the Chinese Industrial Enterprise Database (CIED), which is developed and maintained by the Chinese National Bureau of Statistics. This data records basic corporate information and various financial indicators from 2003 to 2010, spanning 37 industries in the two-digit manufacturing industry (for more details, please see Cai and Liu, 2009).

\subsection{Variables description}

Chinese foreign firms are mainly divided into two types: one is the exclusively foreign-owned enterprise, and the other is the equity joint ventures. The equity joint ventures in China refer to an enterprise whose foreign capital accounts for more than $25 \%$ of its registered capital. The 
foreign firms in this article include these two types. Our variables and their explanations are as follows:

(1) Dependent variable (EXIT): Following Weintraub et al. (2008), EXIT it is a dummy variable, which equals to1 if firm $\mathrm{i}$ exits in year $\mathrm{t}$, and 0 otherwise. If a firm appears in year $\mathrm{t}$ but does not appear in year $\mathrm{t}+1$, it means that the firm has exited from the market in year $\mathrm{t}$. If a firm appeared in the market in both years $t$ and $t+1$, it means that the firm did not withdraw from the market in year t. Besides, we delete samples of companies that re-enter after exiting.

(2) Independent variable $\left(E R_{c t}\right)$ : Many studies measure ER in annual fee on waste discharge (Smarzynska, 2001; Fredriksson, 2002; Lee, 2020), but it does not indicate the ultimate pollution control effect. Based on data availability, we collected the sulfur dioxide removal rate, industrial smoke removal rate, and industrial wastewater purification rate from 2003 to 2010 at the city level in China. Following to Liu and Lin (2018), we calculate the weighted index of three pollution reduction indicators to replace the degree of ER. The calculation method is as follows:

Since different pollutant indicators cannot be directly compared, the first step is to standardize these indicators:

$$
U S_{i j}^{S}=\left(U E_{i j}-\min U E_{j}\right) /\left(\max U E_{j}-\min U E_{j}\right)
$$

Where $U E_{i j}$ represents the emission reduction indicator of $\mathrm{j}$ pollutants in city $\mathrm{i}, \max U E_{j}$ and $\min U E_{j}$ are the maximum and minimum values of pollutant $\mathrm{j}$ in all cities, and $U S_{i j}^{S}$ represents the standardized reduction indicator of $\mathrm{j}$ pollutant in city $\mathrm{i}$.

Each city has a different level of pollutant emissions, and the proportion of various pollutants in the city is also different. It is necessary to calculate the weighted coefficient for each city. The calculation method of the weighted sum coefficient $S_{i j}$ is as follows:

$$
S_{i j}=\left(q_{i j} / \sum_{i} q_{i j}\right) /\left(\operatorname{Ind}_{i} / \sum_{i} \operatorname{Ind}_{i}\right)
$$

where $q_{i j}$ represents the emission of pollutant $\mathrm{j}$ in city $\mathrm{i}$, and $I n d_{i}$ represents the gross industrial output of city $\mathrm{i}$.

Finally, the index $E R_{c t}$ of the city $\mathrm{i}$ in year $\mathrm{t}$ is calculated as follows:

$$
E R=\sum_{j} S_{i j} \times U S_{i j}^{S}
$$

$E R_{c t}$ is the city-level panel data from 2003 to 2010 . This index represents the pollution reduction performance and the intensity of ER in different cities. 
(3) Moderating variables (MC): We use two indicators to measure market competition. The first one (MC1) is the marketization index. It indicates that the degree of liberalization of the regional market. The second one is the proportion of the gross industrial output of non-SOEs to the gross industrial output of the region (MC2). The government directly supervises and regulates SOEs (Zhang et al, 2017), therefore the larger the indicator, the higher the degree of marketization.

(4) Instrumental variables: Given the potential endogeneity, we adopt the instrumental variable approach to solve this problem. Following Hering et al. (2014), we choose the ventilation coefficient (VC) as the instrumental variable of ER. In the standard Box model of atmospheric pollution, the ventilation coefficient is considered of the determinant of air pollution's dispersion speed. It determines the height at which pollutants disperse in the atmosphere (Jacobsen, 2002). This data comes from the European Centre for Medium-Term Weather Forecasting (ECMWF) ERA-Interim data set (for more details, please see Hering et al., 2014).

Furthermore, we also use city standard coal consumption (SC) data in 1985 as another instrumental variable for ER. Because the ventilation coefficient and the consumption of standard coal in 1985 belong to natural and historical factors. They are related to pollution emissions but have little to do with current firm behavior. Therefore, we think that the two instrumental variables are exogenous and associated with the independent variables.

(5) Control variables: We add characteristic variables at the city level and the firm level as the control variables, such as regional GDP per capita (PGDP), regional salary per capita (CS), firm salary per capita (FS). Table 1 shows the explanations of all variables.

Table 1. Descriptive of variables

\begin{tabular}{|c|c|c|c|c|c|}
\hline Variables & Definition & Observations & Min & Max & Mean \\
\hline EXIT & $\begin{array}{l}\text { Equal to1 if firm exits in year } t \text {, and } 0 \text { other- } \\
\text { wise. }\end{array}$ & 293,499 & 0 & 1 & 0.122 \\
\hline ER & $\begin{array}{l}\text { Weighted sum indicators of three pollutant } \\
\text { emission reduction data }\end{array}$ & 293,499 & 0.145 & 8.023 & 1.436 \\
\hline PGDP & Logarithm of regional actual GDP per capita & 293,499 & 3.286 & 7.820 & 6.035 \\
\hline PIND & $\begin{array}{l}\text { Logarithm of regional actual industrial output } \\
\text { per capita }\end{array}$ & 293,499 & 1.254 & 8.700 & 5.457 \\
\hline FDI & $\begin{array}{l}\text { The proportion of the gross industrial output } \\
\text { of foreign firms of the region }\end{array}$ & 293,499 & 0.0007 & 0.9400 & 0.453 \\
\hline CS & Logarithm of regional actual salary per capita & 293,499 & 2.283 & 11.828 & 10.124 \\
\hline
\end{tabular}




\begin{tabular}{|c|c|c|c|c|c|}
\hline FS & Logarithm of firm actual salary per capita & 293,499 & 1.130 & 4.767 & 2.798 \\
\hline FAGE & Logarithm of firm age & 293,499 & 0 & 3.135 & 1.799 \\
\hline FLOW & $\begin{array}{l}\text { The ratio of firm prime operating revenue to } \\
\text { circulating assets }\end{array}$ & 293,499 & 0.281 & 29.95 & 3.367 \\
\hline FSIZE & Logarithm of firm gross assets & 293,499 & 7.636 & 14.38 & 10.38 \\
\hline $\mathrm{MC1}$ & Logarithm of marketization & 279,616 & 0.9555 & 2.4681 & 2.224 \\
\hline MC2 & $\begin{array}{l}\text { The proportion of the gross industrial output } \\
\text { of non-SOEs to the region }\end{array}$ & 293,499 & 0.2841 & 0.9635 & 0.7397 \\
\hline $\mathrm{VC}$ & Logarithm of regional ventilation coefficient & 293,499 & 6.560 & 8.211 & 7.471 \\
\hline $\mathrm{SC}$ & Logarithm of city standard coal consumption & 159,676 & 0 & 7.191 & 3.960 \\
\hline
\end{tabular}

278

\section{Empirical results}

\subsection{Causality between ER and foreign firms' exit behavior}

Based on Eq (1), we estimate the impact of ER on the foreign firms' exit behavior. Table 2 presents the results of all regressions. Column (1) reports the result without control variables. We can find that the ER's coefficient is significantly negative at $1 \%$ level. After controlling the city, industry, and year fixed effects and other variables in column (2), ER's coefficient is still significantly negative. Column (3) is the average marginal effect of the probit model. The result indicates the intensity of ER increases by $1 \%$, and the probability of withdrawal of foreign enterprises decreases by $0.01 \%$. As expected, the strengthening of ER reduce the exit probability of foreign firms rather than inducing foreign firms withdrawal. Our hypothesis 1 is confirmed.

To test the results' robustness, we conduct the three robustness tests: (1) Considering the financial crisis. The 2008 financial crisis caused a large number of companies to withdraw from the market. In order to eliminate the impact of this factor, we only use the data from 2003 to 2007 for estimation. (2) Considering the error of statistical threshold. The CIED includes all SOEs and non-SOEs whose annual business income is greater than 5 million Chinese Yuan (CNY). If a company's sales fall below 5 million yuan, it may only withdraw from the database because of the shrinking of business income, but not really withdraw from the market. To remove this error, we use samples with incomes more than 20 million Yuan for estimation. (3) Using linear probability model (LPM). When the dependent variable is $0-1$, OLS estimation is still unbiased, although it has heteroscedasticity. Therefore, this paper uses the LPM to explore 


\begin{tabular}{|c|c|c|c|c|c|c|}
\hline \multirow[t]{2}{*}{ Variables } & (1) & (2) & (3) & (4) & (5) & (6) \\
\hline & $\begin{array}{l}\text { No control } \\
\text { variables }\end{array}$ & $\begin{array}{c}\text { Baseline } \\
\text { model }\end{array}$ & $\begin{array}{l}\text { Marginal ef- } \\
\text { fect }\end{array}$ & $\begin{array}{c}\text { Year before } \\
2008\end{array}$ & $\begin{array}{c}\text { Sales > } 20 \\
\text { million yuan }\end{array}$ & LPM \\
\hline \multirow[t]{2}{*}{ ER } & $-0.0563 * * *$ & $-0.0547 * *$ & $-0.0100 * *$ & $-0.0897 * * *$ & $-0.0934 * * *$ & $-0.0089 *$ \\
\hline & $(0.0202)$ & $(0.0269)$ & $(0.0049)$ & $(0.0266)$ & $(0.0331)$ & $(0.0048)$ \\
\hline \multirow[t]{2}{*}{ PGDP } & & 0.0604 & 0.0110 & 0.0419 & -0.1116 & 0.0054 \\
\hline & & $(0.0907)$ & $(0.0165)$ & $(0.0923)$ & $(0.1330)$ & $(0.0182)$ \\
\hline \multirow[t]{2}{*}{ FSIZE } & & $-0.2247 * * *$ & $-0.0418 * * *$ & $-0.1932 * * *$ & $-0.1005 * * *$ & $-0.0383 * * *$ \\
\hline & & $(0.0106)$ & $(0.0019)$ & $(0.0125)$ & $(0.0086)$ & $(0.0017)$ \\
\hline \multirow[t]{2}{*}{ PIND } & & 0.0527 & 0.0096 & 0.0765 & 0.0722 & 0.0121 \\
\hline & & $(0.0504)$ & $(0.0092)$ & $(0.0469)$ & $(0.0677)$ & $(0.0107)$ \\
\hline \multirow[t]{2}{*}{ FS } & & $-0.0841 * * *$ & $-0.0410 * * *$ & 0.0009 & $0.0320 * * *$ & $-0.0206 * * *$ \\
\hline & & $(0.0161)$ & $(0.0029)$ & $(0.0155)$ & $(0.0121)$ & $(0.0035)$ \\
\hline \multirow[t]{2}{*}{$\mathrm{CS}$} & & 0.1618 & 0.0295 & 0.1945 & $0.4586^{* *}$ & 0.0245 \\
\hline & & $(0.1035)$ & $(0.0189)$ & $(0.1200)$ & $(0.1873)$ & $(0.0180)$ \\
\hline \multirow[t]{2}{*}{ FAGE } & & $0.0877 * * *$ & $0.0160 * * *$ & $0.0831 * * *$ & $0.0577 * * *$ & $0.0157 * * *$ \\
\hline & & $(0.0111)$ & $(0.0020)$ & $(0.0114)$ & $(0.0121)$ & $(0.0019)$ \\
\hline \multirow[t]{2}{*}{ Flow } & & $-0.0121 * * *$ & $-0.0022 * * *$ & $-0.0123 * * *$ & $0.0079 * * *$ & $-0.0022 * * *$ \\
\hline & & $(0.0024)$ & $(0.0004)$ & $(0.0027)$ & $(0.0014)$ & $(0.0004)$ \\
\hline \multirow[t]{2}{*}{ FDI } & & $-0.6571 * *$ & $-0.1198 * *$ & $-0.7601 *$ & -0.3946 & $-0.1252 * *$ \\
\hline & & $(0.3233)$ & $(0.0588)$ & $(0.4224)$ & $(0.3955)$ & $(0.0588)$ \\
\hline Obs & 293423 & 293423 & 293423 & 240,260 & 194,013 & 293499 \\
\hline City FE & YES & YES & YES & YES & YES & YES \\
\hline Industry FE & YES & YES & YES & YES & YES & YES \\
\hline Year FE & YES & YES & YES & YES & YES & YES \\
\hline
\end{tabular}
the robustness of the results.

Columns (4)-(6) are the results of three robustness tests respectively. The coefficients of ER are all still significantly negative, which are consistent with the results of the basic regression. In addition, we have also investigated whether there is a U-shaped effect between ER and foreign capital withdrawal, but the results show that there is no such effect.

\section{Table 2. Regression of ER's Impact on foreign firms' exit}

\subsection{Endogeneity}

313 We also pay attention to the endogenous problems such as missing variables and bidirectional 314 causality, which may lead to the bias of results. To address the problem, we introduce the ven315 tilation coefficient as an instrumental variable in the first column of Table 3 and estimate Eq (1) 
by the two-stage least square method. The result implicates that the coefficient of ER becomes

317 significantly negative at $1 \%$ level and larger. And the KPF value is greater than 10 , which indi318 cates that the instrumental variable has passed the weak identification test.

319 In the third column, we use both ventilation coefficient and city standard coal consumption 320 in 1985 as the instrumental variables. The coefficient of ER remains significantly negative at $3211 \%$ level. We also conducted weak identification test (KPF) and overidentification test (Hansen $322 \mathrm{~J}$ ) on 2 SLS. It is shown that there is no weak identification problem and the instrumental vari323 ables are exogenous. In summary, after controlling endogeneity, the impact of ER on foreign 324 firms' exit is in line with the basic regression's result.

Table 3. IV Regression of ER's Impact on foreign firms' exit

\begin{tabular}{|c|c|c|c|c|}
\hline \multirow[t]{2}{*}{ Variables } & (1) & (2) & (3) & (4) \\
\hline & Exit & First-stage ER & Exit & First-stage ER \\
\hline \multirow[t]{2}{*}{ ERS } & $-0.1965 * * *$ & & $-0.1124 * * *$ & \\
\hline & $(0.0277)$ & & $(0.0219)$ & \\
\hline \multirow[t]{2}{*}{$\mathrm{VC}$} & & $-0.4865 * * *$ & & $-0.8042 * * *$ \\
\hline & & $(0.0196)$ & & $(0.0326)$ \\
\hline \multirow[t]{2}{*}{$\mathrm{SC}$} & & & & $0.0085 * * *$ \\
\hline & & & & $(0.0023)$ \\
\hline \multirow[t]{2}{*}{ PGDP } & $-0.1542 * * *$ & $-0.7754 * * *$ & $-0.1453 * * *$ & $-1.1119 * * *$ \\
\hline & $(0.0208)$ & $(0.0118)$ & $(0.0234)$ & $(0.0167)$ \\
\hline \multirow[t]{2}{*}{ FSIZE } & $-0.0722 * * *$ & $0.0074 * * *$ & $-0.0662 * * *$ & 0.0054 \\
\hline & $(0.0019)$ & $(0.0023)$ & $(0.0025)$ & $(0.0036)$ \\
\hline \multirow[t]{2}{*}{ PIND } & $0.1205 * * *$ & $0.5010 * * *$ & $0.1013 * * *$ & $0.5945 * * *$ \\
\hline & $(0.0145)$ & $(0.0067)$ & $(0.0136)$ & $(0.0093)$ \\
\hline \multirow[t]{2}{*}{ FS } & $-0.0330 * * *$ & $0.0120 * * *$ & $-0.0363 * * *$ & $0.0105 * * *$ \\
\hline & $(0.0015)$ & $(0.0018)$ & $(0.0019)$ & $(0.0028)$ \\
\hline \multirow[t]{2}{*}{$\mathrm{CS}$} & $-0.0599 * * *$ & $-0.4560 * * *$ & $-0.0182 *$ & $-0.4630 * * *$ \\
\hline & $(0.0135)$ & $(0.0240)$ & $(0.0111)$ & $(0.0300)$ \\
\hline \multirow[t]{2}{*}{ FAGE } & $0.0360 * * *$ & $0.0066^{*}$ & $0.0332 * * *$ & 0.0040 \\
\hline & $(0.0020)$ & $(0.0029)$ & $(0.0025)$ & $(0.0044)$ \\
\hline \multirow[t]{2}{*}{ Flow } & $-0.0022 * * *$ & -0.0005 & $-0.0016 * * *$ & $-0.0013 * *$ \\
\hline & $(0.0003)$ & $(0.0003)$ & $(0.0003)$ & $(0.0005)$ \\
\hline \multirow[t]{2}{*}{ FDI } & $-0.0710 * * *$ & $-0.2350 * * *$ & $0.1022 * * *$ & $0.1357 * * *$ \\
\hline & $(0.0187)$ & $(0.0221)$ & $(0.0262)$ & $(0.0409)$ \\
\hline Obs & 279,594 & 279,594 & 151,882 & 151,882 \\
\hline Firm FE & YES & YES & YES & YES \\
\hline Year FE & YES & YES & YES & YES \\
\hline Kleibergen-Paaprk Wald F & & 614.226 & & 306.378 \\
\hline
\end{tabular}




\subsection{Test for the moderating effect of market competition}

330

331

Table 4 presents the results of Eq (2), which evaluates the moderating effect of market competition between ER and foreign enterprises' exit behavior. We first use the marketization index (MC1) as a proxy variable of market competition. To ensure our findings' validity, we then introduce MC2 as another proxy variable of market competition.

The coefficients of ER*MC1 and ER*MC2 are -0.1977 and -0.1627 respectively in column (1) and column (3), and both are significantly negative at the $1 \%$ level. The results indicate that market competition has a significantly moderating effect on the relationship between ER and foreign firms' exit behavior. In other words, ER are more likely to inhibit foreign firms' leaving China, in cities with a higher degree of marketization. Our results are consistent with Javeed et al. (2020). As we mentioned above, in the fierce market competition environment, when facing the negative impact, such as stricter ER, foreign firms can better use their technological and scale advantages to improve performance. Thus, the probability of foreign firms leaving China is reduced. Besides, we apply the LPM to estimate moderating effects of market competition, and the results remain robust.

Table 4. Test for moderating effect of market competition

\begin{tabular}{|c|c|c|c|c|}
\hline \multirow[t]{3}{*}{ Variables } & (1) & (2) & (3) & (4) \\
\hline & \multicolumn{2}{|c|}{ Market Competition 1} & \multicolumn{2}{|c|}{ Market Competition 2} \\
\hline & Probit & LPM & Probit & LPM \\
\hline \multirow[t]{2}{*}{ ER } & $-0.0661 * * *$ & $-0.0120 * * *$ & $-0.0608 * * *$ & $-0.0101 * *$ \\
\hline & $(0.0184)$ & $(0.0039)$ & $(0.0210)$ & $(0.0041)$ \\
\hline \multirow[t]{2}{*}{$\mathrm{MC1}$} & -0.3541 & -0.0758 & & \\
\hline & $(0.6457)$ & $(0.1174)$ & & \\
\hline \multirow[t]{2}{*}{$\mathrm{ER} * \mathrm{MC} 1$} & $-0.1977 * * *$ & $-0.0367 * * *$ & & \\
\hline & $(0.0521)$ & $(0.0118)$ & & \\
\hline \multirow[t]{2}{*}{$\mathrm{MC} 2$} & & & 0.4224 & -0.0005 \\
\hline & & & $(0.2661)$ & $(0.0132)$ \\
\hline \multirow[t]{2}{*}{$\mathrm{ER} * \mathrm{MC} 2$} & & & $-0.1627 * * *$ & $-0.0081 * *$ \\
\hline & & & $(0.0604)$ & $(0.0038)$ \\
\hline \multirow[t]{2}{*}{ PGDP } & 0.1230 & 0.0179 & 0.0304 & 0.0004 \\
\hline & $(0.1191)$ & $(0.0237)$ & $(0.0944)$ & $(0.0186)$ \\
\hline FSIZE & $-0.2093 * * *$ & $-0.0348 * * *$ & $-0.2247 * * *$ & $-0.0383 * * *$ \\
\hline
\end{tabular}




\begin{tabular}{ccccc}
\hline & $(0.0120)$ & $(0.0021)$ & $(0.0106)$ & $(0.0017)$ \\
PIND & 0.0403 & 0.0057 & 0.0796 & 0.0150 \\
FS & $(0.0593)$ & $(0.0115)$ & $(0.0546)$ & $(0.0118)$ \\
& -0.0028 & -0.0013 & $-0.0853 * * *$ & $-0.0208^{* * *}$ \\
CS & $(0.0109)$ & $(0.0021)$ & $(0.0161)$ & $(0.0035)$ \\
& 0.2591 & 0.0400 & 0.1362 & 0.0199 \\
FAGE & $(0.1628)$ & $(0.0273)$ & $(0.1024)$ & $(0.0181)$ \\
& $0.0854 * * *$ & $0.0148 * * *$ & $0.0879 * * *$ & $0.0158^{* * *}$ \\
Flow & $(0.0112)$ & $(0.0019)$ & $(0.0110)$ & $(0.0019)$ \\
& $-0.0109 * * *$ & $-0.0018 * * *$ & $-0.0122 * * *$ & $-0.0022^{* * *}$ \\
FDI & $(0.0025)$ & $(0.0004)$ & $(0.0025)$ & $(0.0004)$ \\
& -0.3569 & -0.0436 & $-0.9816 * * *$ & $-0.1782^{* * *}$ \\
Obs & $(0.3771)$ & $(0.0744)$ & $(0.3805)$ & $(0.0672)$ \\
City FE & 279,544 & 279,616 & 293,423 & 293,499 \\
Industry FE & YES & YES & YES & YES \\
Year FE & YES & YES & YES & YES \\
\hline
\end{tabular}

347

348

349

350

351

352

353

354

355

356

357

358

359

360

361

362

363

364

Robust standard errors are in parentheses; asterisks ***, **, and * denote significance at the $1 \%, 5 \%$, and $10 \%$ levels, respectively.

\subsection{Heterogeneity test}

As ER have a great impact on high-pollution industries, the effect of ER in reducing foreign enterprises' withdrawal should be different. Besides, there is a noticeable gap in Chinese regional economic development and policy implementation. To examine the difference, we take on the industrial and regional heterogeneity test in Table 5, respectively.

First, according to the geographical location, we divide the companies into two types: the eastern regions and the non-eastern regions. As shown in the first and second columns, the impact of ER on the foreign firms' exit in the east of China is significantly negative, which is in line with our expectation. While the impact is not significant in the non-eastern areas. Dean et al. (2009) suggest that the Chinese non-eastern regions' economic activities are dominated by industries related to natural resources, which may be more sensitive to ER policies. The improvement of ER cannot lead to technological innovation and productivity improvement of enterprises in non-eastern regions. In addition, the degree of marketization in Chinese noneastern regions is lower; therefore, the role of market competition is not prominent.

Second, we divide samples into three industrial types on basis of the degree of pollution 
emissions: heavy pollution, medium pollution and light pollution, and then do grouping regression. The results are shown in columns 3-5. We find that all the regression coefficients of ER are negative, but only the medium pollution industries are significant. On the one hand, the costs of pollution control in the heavy pollution industries are higher, and ER have a more negative impact on serious pollution firms. Therefore, more stringent ER cannot reduce the exit probability of enterprises in heavy pollution industries. On the other hand, ER have less impact on the costs and performance of companies in the cleaning industries, therefore the coefficient is not significant. The results are consistent with Bu and Wagner (2016).

\section{Table 5. Heterogeneity test}

\begin{tabular}{|c|c|c|c|c|c|}
\hline Variables & $\begin{array}{c}(1) \\
\text { Eastern }\end{array}$ & $\begin{array}{c}\text { (2) } \\
\text { non-Eastern }\end{array}$ & $\begin{array}{c}\text { (3) } \\
\text { Heavy pollution }\end{array}$ & $\begin{array}{c}\text { (4) } \\
\text { Medium pollution }\end{array}$ & $\begin{array}{c}\text { (5) } \\
\text { Light pollution }\end{array}$ \\
\hline \multirow[t]{2}{*}{ ER } & $-0.0634 * *$ & 0.0221 & -0.0322 & $-0.0835^{* *}$ & -0.0442 \\
\hline & $(0.0287)$ & $(0.0362)$ & $(0.0351)$ & $(0.0327)$ & $(0.0305)$ \\
\hline \multirow[t]{2}{*}{ PGDP } & 0.0411 & -0.1992 & -0.0001 & 0.0034 & 0.1432 \\
\hline & $(0.0975)$ & $(0.3220)$ & $(0.1203)$ & $(0.0964)$ & $(0.1046)$ \\
\hline \multirow[t]{2}{*}{ FSIZE } & $-0.2327 * * *$ & $-0.1318 * * *$ & $-0.1986 * * *$ & $-0.2385^{* * *}$ & $-0.2353 * * *$ \\
\hline & $(0.0105)$ & $(0.0145)$ & $(0.0111)$ & $(0.0111)$ & $(0.0120)$ \\
\hline \multirow[t]{2}{*}{ PIND } & 0.0453 & $0.9670^{* * *}$ & 0.0588 & 0.0968 & 0.0240 \\
\hline & $(0.0543)$ & $(0.2636)$ & $(0.0593)$ & $(0.0656)$ & $(0.0562)$ \\
\hline \multirow[t]{2}{*}{ FS } & $-0.0799 * * *$ & $-0.1378 * * *$ & $-0.1305 * * *$ & $-0.0828 * * *$ & $-0.0618^{* * *}$ \\
\hline & $(0.0170)$ & $(0.0233)$ & $(0.0195)$ & $(0.0155)$ & $(0.0191)$ \\
\hline \multirow[t]{2}{*}{$\mathrm{CS}$} & 0.1505 & -0.2969 & $0.5737 * * *$ & 0.0091 & 0.1704 \\
\hline & $(0.1071)$ & $(0.4124)$ & $(0.1696)$ & $(0.0810)$ & $(0.1190)$ \\
\hline \multirow[t]{2}{*}{ FAGE } & $0.0874 * * *$ & $0.1004 * * *$ & $0.1416 * * *$ & $0.1062 * * *$ & $0.0520 * * *$ \\
\hline & $(0.0119)$ & $(0.0176)$ & $(0.0145)$ & $(0.0137)$ & $(0.0118)$ \\
\hline \multirow[t]{2}{*}{ Flow } & $-0.0133 * * *$ & -0.0016 & $-0.0089^{* * *}$ & $-0.0097 * * *$ & $-0.0155^{* * *}$ \\
\hline & $(0.0027)$ & $(0.0027)$ & $(0.0025)$ & $(0.0031)$ & $(0.0027)$ \\
\hline \multirow[t]{2}{*}{ FDI } & $-0.6451 *$ & -0.0837 & -0.2402 & $-0.8055^{* *}$ & $-0.7851 * *$ \\
\hline & $(0.3443)$ & $(0.5971)$ & $(0.5227)$ & $(0.3571)$ & $(0.3172)$ \\
\hline Obs & 274,559 & 18,864 & 71,937 & 90,687 & 130,499 \\
\hline City FE & YES & YES & YES & YES & YES \\
\hline Industry FE & YES & YES & YES & YES & YES \\
\hline Year FE & YES & YES & YES & YES & YES \\
\hline
\end{tabular}

Robust standard errors are in parentheses; asterisks ***, **, and * denote significance at the $1 \%, 5 \%$, and $10 \%$ levels, respectively.

\subsection{Mechanism analysis}

379 The literature indicates that ER can improve corporate performance (Porter, 1991; Javeed, 
2020). The high degree of competition forces firms to be innovative and differentiated with high-quality products to gain maximum profit (Ammann et al. 2013; Byun et al. 2012). The foreign firms have no reason to leave China if their performance is improved. Therefore, performance can be viewed as an intermediate channel for the relationship between ER and firms' exit behavior.

In order to examine the Eq (3), we use three ways to measure $P e r_{i t}$. The first one is firm market share, which is the proportion of the firms' gross output to industry's gross output. The second one is firm profit margin, which is firm financial performance. The third is firm total factor productivity (TFP). We use the LP method to estimate the firm TFP, representing the enterprise's technological level.

The underlying assumption of this article is that the performance of foreign enterprises caused by ER is better than that of domestic enterprises. Therefore, we also analyze the impact of ER on domestic companies. As shown in Table 6, ER have a significant negative impact on market share and profits for the domestic firms but have no significant effect on TFP. However, ER have a significant positive impact on the three corporate performance indicators of foreign firms. These results have confirmed our hypothesis, on the one hand, the stricter ER stimulate innovation and improve the productivity of foreign firms. On the other hand, ER reduce the market share of domestic enterprises, and then make foreign enterprises obtain larger market share and higher profit margin through competition. Therefore, ER reduce the outflow of foreign capital.

Table 6. Mechanism analysis

\begin{tabular}{ccccccc}
\hline Variables & \multicolumn{3}{c}{ Domestic firms } & \multicolumn{3}{c}{ Foreign firms } \\
& $(1)$ & $(2)$ & $(3)$ & $(1)$ & $(2)$ & $(3)$ \\
& Market Share & Profit & TFP & Market Share & Profit & TFP \\
\hline ER & $-0.0021 *$ & $-0.0003 *$ & -0.0025 & $0.0139 * * *$ & $0.0048 * * *$ & $0.0382 * * *$ \\
& $(0.0012)$ & $(0.0002)$ & $(0.0024)$ & $(0.0039)$ & $(0.0005)$ & $(0.0048)$ \\
FSIZE & $0.4762 * * *$ & $0.0110 * * *$ & $0.2727 * * *$ & $0.6400 * * *$ & $0.0220 * * *$ & $0.4490 * * *$ \\
& $(0.0023)$ & $(0.0003)$ & $(0.0037)$ & $(0.0055)$ & $(0.0006)$ & $(0.0059)$ \\
FS & $0.2304 * * *$ & $0.0018 * * *$ & $0.1926 * * *$ & $0.1582 * * *$ & $0.0057 * * *$ & $0.1757 * * *$ \\
& $(0.0015)$ & $(0.0002)$ & $(0.0028)$ & $(0.0032)$ & $(0.0004)$ & $(0.0042)$ \\
FAGE & $0.0320 * * *$ & -0.0000 & $0.0344 * * *$ & $0.0661 * * *$ & $0.0017 * * *$ & $0.0558 * * *$ \\
& $(0.0022)$ & $(0.0003)$ & $(0.0040)$ & $(0.0057)$ & $(0.0007)$ & $(0.0064)$ \\
FDI & $-0.0647 * * *$ & $-0.0045 * * *$ & $-0.2435 * * *$ & -0.0693 & $-0.0676 * * *$ & $-0.2910 * * *$
\end{tabular}




\begin{tabular}{ccccccc} 
& $(0.0057)$ & $(0.0006)$ & $(0.0103)$ & $(0.0484)$ & $(0.0053)$ & $(0.0551)$ \\
Flow & $0.0255^{* * *}$ & $-0.0003 * * *$ & $0.0214 * * *$ & $0.0644 * * *$ & $0.0017 * * *$ & $0.0549 * * *$ \\
& $(0.0002)$ & $(0.0000)$ & $(0.0002)$ & $(0.0008)$ & $(0.0001)$ & $(0.0008)$ \\
PGDP & $0.1771 * * *$ & $-0.0161 * * *$ & $0.3476 * * *$ & $0.0778 * * *$ & $0.0102 * * *$ & $0.0896 * * *$ \\
& $(0.0092)$ & $(0.0012)$ & $(0.0176)$ & $(0.0139)$ & $(0.0018)$ & $(0.0177)$ \\
PIND & $0.2205 * * *$ & $0.0177 * * *$ & $0.1368 * * *$ & $0.0228 * * *$ & $-0.0052 * * *$ & $0.0739 * * *$ \\
& $(0.0096)$ & $(0.0012)$ & $(0.0161)$ & $(0.0077)$ & $(0.0013)$ & $(0.0100)$ \\
CS & $-0.0753 * * *$ & $-0.0107 * * *$ & -0.0225 & $-0.0387 * * *$ & 0.0024 & $0.1367 * * *$ \\
& $(0.0094)$ & $(0.0013)$ & $(0.0205)$ & $(0.0134)$ & $(0.0017)$ & $(0.0177)$ \\
Obs & $1,176,327$ & $1,195,584$ & 682,325 & 283,205 & 293,499 & 293,499 \\
Firm FE & YES & YES & YES & YES & YES & YES \\
Year FE & YES & YES & YES & YES & YES & YES \\
\hline Robust standard errors are in parentheses; asterisks $* * * * *$, and $*$ denote significance at the $1 \%, 5 \%$, and $10 \%$ levels, respectively.
\end{tabular}

403

404

405

406

407

408

409

410

411

412

413

414

415

416

417

418

419

420

421

422

423

\section{Discussion}

The empirical results confirm our hypotheses about the impact of the ER on foreign firms, and provid new evidence for $\mathrm{PHH}$ as well.

Our hypothesis 1 shows that the ER reduce the probability of foreign firms leaving China. The results are consistent with Dijkstra et al. (2011). Many studies have shown that the ER reduce the influx of FDI (Cai et al., 2016). However, our evidence indicates that the inflow of FDI is different from its outflow. Multinational enterprises need to pay sunk costs and additional switching costs to withdraw from the host country's market. The ER prompt foreign firms with scale and technological advantages to gain greater cost and competitive advantages. There is no reason for multinational enterprises to withdraw from China.

The second hypothesis implicates that the ER have a more significant effect on reducing foreign firms' exit from regions with higher marketization degree. As long as the market is large enough, the ER do not cause companies to relocate (Sanna-Randaccio and Sestini 2012). If a region is controlled by the government and monopolized by the SOEs, the foreign firms cannot use their competitiveness to improve performance. The free market competition environment can alleviate the contradiction between environmental protection and FDI. This result is in line with Javeed et al. (2020).

In addition, we document the mechanism of the results above. Our results reveal that the ER improve the performance of foreign firms but reduce the performance of domestic ones. Most 
of the foreign firms in China come from developed countries. They are more prominent in scale and more advanced in technology. As a result, the foreign firms are less negatively affected by the ER (Dijkstra et al. 2011), and the competitiveness of foreign enterprises becomes greater compared with Chinese companies. That is why the ER reduce the probability of divestment of FDI.

\section{Conclusion}

The purpose of this study is to investigate whether the ER lead to foreign firms leaving China. By using firm-level data and considering endogeneity, the results propose that the ER have reduced the probability of divestment of FDI in China. In addition, we introduce the moderating effect of market competition. The results indicate that the ER's effect in reducing foreign firms' exit probability is more significant in places with a higher marketization degree. The reason is that the ER have improved the performance of foreign firms. The results implicate that the ER and economic development are not opposed to each other, which provides a new evidence for PHH and Porter hypothesis.

Based on this article, it is necessary to continue to carry out reasonable environmental protection policies to achieve the purpose of protecting the environment and attracting FDI. The government should provide an orderly and good market competition environment, and let enterprises play their competitive advantage. At the same time, domestic enterprises in developing countries should also improve their competitive advantages to meet the challenges brought by the strengthening of ER.

It is worth noting that this research may suffer from some limitations, which need further investigation. First, the companies in developing countries are less competitive than multinational enterprises from developed countries. Although the environmental protection policies of developing countries will not lead to the divestment of FDI, the ER may harm domestic enterprises. Therefore, future research should focus on how to protect the environment while ensuring the development of domestic and foreign companies. Second, since the implementation of ecological supervision is difficult to observe, more regional heterogeneous adjustment factors, such as institutional quality and corruption, should be considered. 


\section{Funding}

455 This work was supported by the Major Projects of National Social Science Fund of China (Grant

456 No. 71673182).

457 Ethics approval and consent to participate

$458 \quad$ Not applicable

459 Consent for publication

460 Not applicable

$461 \quad$ Availability of data and materials

462 The datasets used and/or analyzed during the current study are available from the corresponding

463 author on reasonable request.

464 Competing interests

465 The authors declare that they have no known competing financial interests or personal relationships

466 that could have appeared to influence the work reported in this study.

\section{Authors' contributions}

468 Lufeng Tai: conceptualization, formal analysis, methodology, software, writing. Linnan Yan: data

469 collection, review and editing, funding acquisition, investigation, supervision. 


\section{References}

472

Ammann, M., Oesch, D., Schmid, M.M., (2013). Product market competition, corporate governance, and firm value: evidence from the EU area. Eur. Financ. Manag. 19, 452e469.

Becker, R., \& Henderson, V. (2000). Effects of air quality regulations on polluting industries. Journal of Political Economy, 108, 379-421.

Berman, E. and Bui, L.T.M. (2001), "Environmental regulation and productivity: evidence from oil refineries", Review of Economics and Statistics, Vol. 83, pp. 498-510.

Berman, E., \& Bui, L. T. (2001). Environmental regulation and productivity: evidence from oil refineries. Review of Economics and Statistics, 83(3), 498-510.

Boiral, O., (2007). Corporate greening through ISO 14001: a rational myth? Organ. Sci. 18, 127e146.

Boyd， G. A. and J. D. McClelland, (1999), "The Impact of Environmental Constraints on Productivity Improvement in Integrated Paper Plants", Journal of Environmental Economics and Management, Vol.38 (2), pp.121 142.

Byun, H.S., Lee, J.H., Park, K.S., (2012). How does product market competition interact with internal corporate governance?: evidence from the Korean economy. Asia Pac. J. Financ. Stud. 41, $377 \mathrm{e} 423$.

Cai, H., \& Liu, Q. (2009). Competition and corporate tax avoidance: Evidence from Chinese industrial firms. The Economic Journal, 119(537), 764-795.

Cai, X., Lu, Y., Wu, M., \& Yu, L. (2016). Does environmental regulation drive away inbound foreign direct investment? Evidence from a quasi-natural experiment in China. Journal of Development Economics, 123, 73-85.

Cao, Y., Wan, N., Zhang, H., Zhang, X., \& Zhou, Q. (2020). Linking environmental regulation and economic growth through technological innovation and resource consumption: Analysis of spatial interaction patterns of urban agglomerations. Ecological Indicators, 112, 106062.

Chichilnisky, G. (1994). North-south trade and the global environment. The American Economic Review, 851-874.

Chung S. (2014). Environmental regulation and foreign direct investment: Evidence from South Korea[J]. Journal of Development Economics, 108: 222-236.

Conrad, K. and D. Wastl, 1995, "The Impact of Environmental Regulation on Productivity in German Industries", Empirical Economics, Vol.20 (4), pp.615 633.

Copeland, B. R., \& Taylor, M. S. (2004). Trade, growth, and the environment. Journal of Economic literature, 42(1), 7-71.

Dasgupta, S., Hong, J. H., Laplante, B., \& Mamingi, N. (2006). Disclosure of environmental violations and stock market in the Republic of Korea. Ecological Economics, 58(4), 759-777.

Dean, Judith M., Lovely, Mary E., Wang, Hua. (2009). Are foreign investors attracted to weak environmental regulations? Evaluating the evidence from China. Journal of Development Economics. 90(1), 1-13.

Dijkstra BR, Mathew A J, Mukherjee A. (2011). Environmental regulation: an incentive for foreign direct investment. Rev. Int. Econ. 19(3):568-78

Dong, Y., Tian, J., \& Ye, J. (2021). Environmental regulation and foreign direct investment: Evidence 
from China's outward FDI. Finance Research Letters, 39, 101611.

Elliott, R. J., \& Zhou, Y. (2013). Environmental regulation induced foreign direct investment. Environmental and Resource Economics, 55(1), 141-158.

Eskeland, G.S., Harrison, A.E. (2003). Moving to greener pastures? Multinationals and the pollution haven hypothesis. J. Dev. Econ. 70, 1-23.

Eslava, M., Haltiwanger, J., Kugler, A., \& Kugler, M. (2013). Trade and market selection: Evidence from manufacturing plants in Colombia. Review of Economic Dynamics, 16(1), 135-158.

Fredriksson, P. G., \& Millimet, D. L. (2002). Is there a 'California effect' in US environmental policymaking?. Regional Science and Urban Economics, 32(6), 737-764.

Gollop, F. M. and M. J. Roberts. (1983). "Environmental Regulations and Productivity Growth: the Case of Fossil-fueled Electric Power Generation”, The Journal of Political Economy, Vol.91 (4), pp.654 674.

Gray, W. B. and R. J. Shadbegian. (2001). "Environmental Regulation and Manufacturing Productivity at the Plant Level”, NBER Working Paper No. w4321.

Gray, W. B. and R. J. Shadbegian. (2003). "Plant Vintage, Technology, and Environmental Regulation", Journal of Environmental Economics and Management, Vol.46 (3) , pp.384 402.

Greaney, T. M., Li, Y., \& Tu, D. (2017). Pollution control and foreign firms' exit behavior in China. Journal of Asian Economics, 48, 148-159.

Greenaway, D., Gullstrand, J., \& Kneller, R. (2008). Surviving globalization. Journal of International Economics, 74(2), 264-277.

Hanna, R. (2010). US environmental regulation and FDI: evidence from a panel ofUS-based multinational firms. Am. Econ. J. Appl. Econ. 2, 158-189.

Henderson, V. (1996). Effects of air quality regulation. American Economic Review, 86, 789-813.

Hering, L. and S. Poncet. (2014). "Environmental Policy and Exports: Evidence from Chinese Cities", Journal of Environmental Economics and Management, 68( 2) ， 296-318.

Hryckiewicz, A. and Kowalewski O. (2011). "Why Do Foreign Banks Withdraw from Other Countries?", International Finance, Vol.14 (1) , pp. 67 102.

Jacobson, M. Z., \& Jacobson, M. Z. (2002). Atmospheric pollution: history, science, and regulation. Cambridge University Press.

Jaffe, A. B., Newell, R. G., \& Stavins, R. N. (2002). Environmental policy and technological change. Environmental and resource economics, 22(1), 41-70.

Jagersma P K, Van Gorp D M. (2003). International divestements--an empirical perspective[J]. Business Horizons, 46(6):61-69.

Javeed, S. A., Latief, R., \& Lefen, L. (2020). An analysis of relationship between environmental regulations and firm performance with moderating effects of product market competition: Empirical evidence from Pakistan. Journal of Cleaner Production, 254, 120197.

Javorcik, B. S., \& Wei, S. (2003). Pollution havens and foreign direct investment: Dirty secret or popular myth? The B.E. Journal of Economic Analysis \& Policy, 3 (2), 1-34.

Kellenberg, Derek K. (2009). An empirical investigation of the pollution haven effect with strategic environment and trade policy. J. Int. Econ. 78, 242-255.

Keller, W., \& Levinson, A. (2002). Pollution abatement costs and foreign direct investment inflows to U.S states. Review of Economics and Statistics, 84, 691-703.

Kim, Y., Rhee, D.-E. (2019). Do stringent environmental regulations attract foreign direct investment in developing countries? Evidence on the "race to the top" from cross-country panel data. Emerg. 
Mark. Finance Trade 55 (12), 2796-2808

Kneller, R., \& Manderson, E. (2012). Environmental regulations and innovation activity in UK manufacturing industries. Resource and Energy Economics, 34(2), 211-235.

Lee, E. (2020). Environmental Regulation and Financial Performance in China: An Integrated View of the Porter Hypothesis and Institutional Theory. Sustainability, 12(23), 10183.

Levinson, A. (1996). Environmental regulations and manufacturers' location choices: Evidence from the census of manufactures. Journal of Public Economics, 62, 5-29.

Levinson, A., \& Taylor, M. S. (2008). Unmasking the pollution haven effect. International Economic Review, 49, 223-254.

Liu, K. \& lin, B. (2018). Research on influencing factors of environmental pollution in china: a spatial econometric analysis. Journal of Cleaner Production, 206(PT.1-1156), 356-364.

Manderson, E., Kneller, R., 2012. Environmental regulations, outward FDI and heterogeneous firms: are countries used as pollution havens? Environ. Resour. Econ. 51, 317-352.

McGuire, M. C. (1982). Regulation, factor rewards, and international trade. Journal of public economics, 17(3), 335-354.

Millimet, Daniel L., Roy, Joyjit. (2016). Empirical tests of the pollution haven hy- pothesis when environmental regulation is endogenous. J. Appl. Econom. 31, 652-677.

Motta, M., \& Thisse, J. F. (1994). Does environmental dumping lead to delocation?. European Economic Review, 38(3-4), 563-576.

Muhammad, B., \& Khan, S. (2019). Effect of bilateral FDI, energy consumption, CO2 emission and capital on economic growth of Asia countries. Energy Reports, 5, 1305-1315.

Porter, M. E., \& Van der Linde, C. (1995). Toward a new conception of the environment-competitiveness relationship. Journal of economic perspectives, 9(4), 97-118.

Porter, M. (1991). America’s Green Strategy. Scientific American, April, p. 96.

Ramanathan, R., Black, A., Nath, P., \& Muyldermans, L. (2010). Impact of environmental regulations on innovation and performance in the UK industrial sector. Management Decision.

Sanna-Randaccio, F., \& Sestini, R. (2012). The impact of unilateral climate policy with endogenous plant location and market size asymmetry. Review of International Economics, 20(3), 580-599.

Santos, A., \& Forte, R. (2020). Environmental regulation and FDI attraction: a bibliometric analysis of the literature. Environmental Science and Pollution Research, 1-16.

Smarzynska, B. K., \& Wei, S. J. (2001). Pollution havens and foreign direct investment: dirty secret or popular myth? (No. w8465). National bureau of economic research.

Wagner, U.J., Timmins, C.D. (2009). Agglomeration effects in foreign direct investment and the pollution haven hypothesis. Environ. Resour. Econ. 43, 231-256.

Weintraub, G., Benkard, L., \& Roy, B. B. (2008). Markov perfect industry dynamics with many firms. Econometrica, 76(6), 1375-1411.

Weiss, J., Stephan, A., \& Anisimova, T. (2019). Well-designed environmental regulation and firm performance: Swedish evidence on the Porter hypothesis and the effect of regulatory time strategies. Journal of Environmental Planning and Management, 62(2), 342-363.

Yang, Y., Niu, G., Tang, D., \& Zhu, M. (2019). Does Environmental Regulation Affect the Introduction of Foreign Direct Investment in China?--Empirical Research Based on the Spatial Durbin Model. Polish Journal of Environmental Studies, 28(1).

Yu, X., \& Li, Y. (2020). Effect of environmental regulation policy tools on the quality of foreign direct investment: An empirical study of China. Journal of Cleaner Production, 270, 122346. 
600

601

602

603

604
Zeng, D. Z., \& Zhao, L. (2009). Pollution havens and industrial agglomeration. Journal of Environmental Economics and Management, 58(2), 141-153.

Zhang, Q., Zhang, S., Ding, Z., \& Hao, Y. (2017). Does government expenditure affect environmental quality? Empirical evidence using Chinese city-level data. Journal of cleaner production, 161, $143-152$. 
Figures
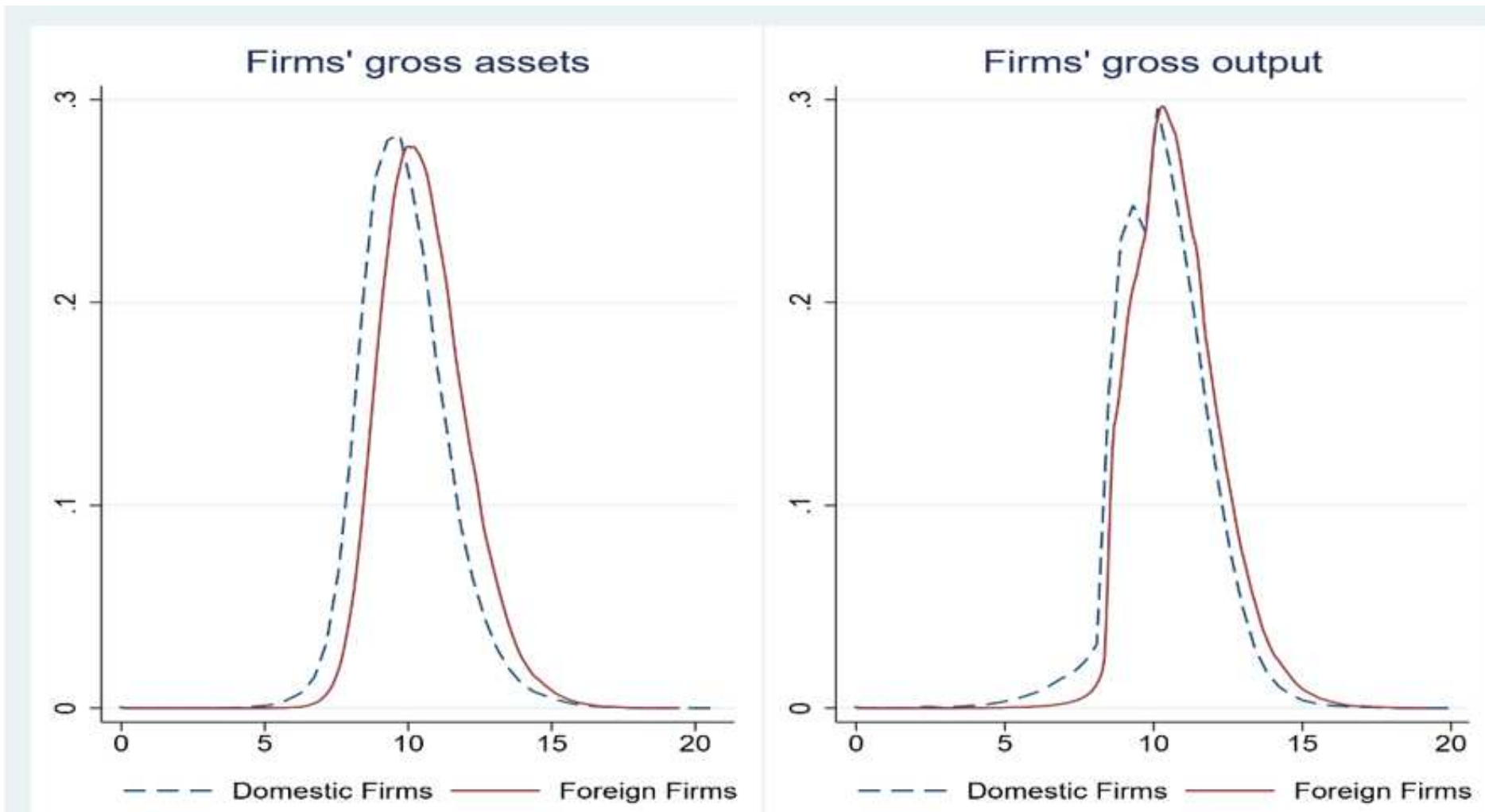

\section{Figure 1}

The kernel density estimation of the scale of foreign firms and domestic firms. 